\title{
Measuring business schools' service quality in an emerging market using an extended SERVQUAL instrument
}

\author{
E.R. Mbise and R.S.J. Tuninga* \\ College of Business Education, P.O. BOX 1968, Dar es Salaam, Tanzania \\ Kingston University London, Kingston Hill, Kingston upon Thames KT2 7LB United Kingdom \\ *To whom all correspondence should be addressed \\ r.tuninga@kingston.ac.uk
}

\begin{abstract}
An extended SERVQUAL instrument is developed, validated and used to measure perceived service quality delivered to students by business schools in an emerging market economy. A longitudinal survey is conducted with selected students in their final year of study from two business schools in an emerging market economy. The use of the extended SERVQUAL model is suggested to monitor student/employee expectations and perceptions during and after the education service delivery process. Students attach different weights to the service quality dimensions. A new Process Outcome dimension is found to substantially add to the SERVQUAL model and is more important than the other dimensions. The validity of the extended SERVQUAL model for practical use is $\alpha>0.95$. Prediction of the level of service quality delivered, using four dimensions, indicates that the level of service quality is explained mostly by Process Outcome and Tangibles dimensions.

It is suggested that using the extended SERVQUAL model as a tool can enable managers of business schools to identify the factors on which students/employees base their quality assessment of the education services they receive. Knowledge of these factors will enable managers in emerging economies to periodically assess, sustain and improve quality of the whole service delivery process. Priorities can be set to allocate scarce resources properly to make effective investment decisions to improve quality per school and in higher education, in general. The paper further suggests that regulatory bodies make use of this model when comparing performance of business schools, focusing on student experiences as a supplement to the traditional performance measures.
\end{abstract}

\section{Introduction}

The quality of higher learning institutions has traditionally been assessed based on performance measures/indicators such as: cost accounting and scientific prestige (Kaplanis, n.d.), number of students and staff, student/lecturer ratio, and student evaluations of teaching and curriculum. Such instruments are mainly developed for management use (Smith, Smith \& Clarke, 2007). Although the instruments may be convenient, their reliability may be debatable due to lack of research to establish their reliability (Cuthbert, 1996). Furthermore, Cuthbert argues that the validity of such instruments may be too low to make sound decisions about course delivery. Audit sessions, conducted by regulatory bodies for quality assurance, check the adherence of business schools to their own set standards (Smith et al., 2007). Performance assessments of such institutions may be based on meeting acceptable minimum requirements and not the best performance. Cuthbert (1996) indicates that questionnaires used to evaluate student experiences in the classroom are not uniform with regard to the constructs used, the number of questions included and the time allowed for completion.

Factors such as the learning approach adopted by the students (Cuthbert, 1996) or large class size, which is beyond the teacher's control, impact on the student experience.
The academic environment is a primary component of service quality in higher learning (UNESCO, 1998). While measuring students' academic performance is important, these measures or indicators are not directly linked to processes- the activities and functions that address their requirements (as customers) in their totality. Assessments of educational institutions, which encompass the student's experience, in addition to other indicators of service quality, would be more comprehensive and reveal a wealth of information about other important aspects of a school.

The key to success of any public or private teaching institution lies in the quality of education services they deliver. In fact, service quality could be the only strong competitive strategy for training and educational institutions (Ford, Joseph, \& Joseph, 1999; Zeithaml, Berry \& Gremler, 2006).

The purpose of this paper is to develop and validate an extended SERVQUAL instrument to measure perceived service quality delivered to students by business schools in an emerging market economy (Tanzania).

Monitoring of the service quality performance of organizations is an important undertaking for quality enhancement, a necessary step towards gaining the competitive advantage over other organizations (Boshoff \& Gray, 2004, Getty \& Getty, 2003; Zeithaml et al., 2006). 
Other business strategies can easily be copied by competitors (Boshoff \& Gray, 2004).

The extended SERVQUAL instrument will be useful to managers of business schools as it helps crystallize the concept of service quality, the discrepancy between students' expectations and the actual performance of the institutions. Specifically, the information gathered informs managers of particular areas in need of improvement and can be used to guide their decision-making. Research and awareness about what students deem important will enable managers to better anticipate and address their particular needs during and after the service encounter. Recognition of differences among student groups will further help policy makers in Tanzania to set priorities and make appropriate investment decisions. This, in turn, will strengthen the educational institutions. The students' service quality assessment of business schools forthcoming from an extended SERVQUAL encompasses the whole student experience, contrary to traditional/ popular tools used to measure lecturers' performance in the classroom only. This instrument empowers students and is an indication that business schools are committed and care for them. The instrument can also be used to monitor expectations, performance and satisfaction levels of business school staff. Given the (Extended) SERVQUAL supplements the traditional performance measures, it will be relevant to (academic) regulatory bodies as well. They can use it to compare the performance of business schools and to focus on students' experience during and after their education (service encounter).

Common performance measures are needed for service quality in the current globalization era in which emerging and mature economies are forging partnerships. It is, therefore, particularly important to test whether the service models developed and applied in mature economies work equally well in emerging economies.

There is still a debate in the literature on the major determinants of service quality (Abdullah, 2005; 2006; Babakus \& Boller, 1992; Bennington \& Cummane, 1997; Bigné, Martínez \& Miquel, 1997; Carman, 1990; Cronin \& Taylor, 1992; Gi-Du Kang, 2004; Ling, Chai \& Piew, 2010; Nel, Boshoff \& Mels, 1997; Nel, Pitt, \& Berthon,1997; Oldfield \& Baron, 2000; Pollack, 2009; Teas, 1993; Wen, 1998). The literature on students as customers and their perceptions of the education services they receive is limited, particularly in the context of emerging markets. This inquiry contributes to the literature on service quality in education as a market sector, and specifically in Tanzania. Although Nel, Pitt and Berthon (1997) conducted a similar study in South Africa using the original SERVQUAL 22 items, only the functional aspects were measured. Since the education service delivery process spans a long time, measurement of the service outcome at the end of service delivery provides a true picture of service quality received. In addition to the functional aspects, this study measures the outcome aspect of the education services received by students using 28 items. Nel, Pitt and Berthon's (1997) population was MBA students while this study's population is final year undergraduate students whose priority areas of service quality may differ from those of MBA students. Furthermore, the authors recommend similar studies undertaking using SERVQUAL for cross-cultural comparisons. This study uses the extended SERVQUAL in a contextually different setting (Tanzania) at two points in time in contrast to cross-sectional studies previously undertaken (e.g. Nel, Pitt \& Berthon, 1997; Pariseau \&McDaniel, 1996).

The definition and measurement of service quality as a construct has been problematic. There has not been agreement as to its definition or its measurement (Getty \& Getty, 2003; Pollack, 2009). Service quality has also been seen as a static construct (O’Neil \& Palmer, 2004). Unlike in the case of the production of physical products, service quality is not a function of statistical measures, looking at defects or managerial judgment (Koslowski III, 2006). Measurement problems have arisen from the intrinsic difficulty of defining this construct. Some researchers wonder if we can actually define it or if we just know it when we see it (Harvey, 2001). Oldfield and Baron (2000) hold that customers cannot see a service but they can see and experience various tangible elements associated with the service. Nonetheless, an instrument that will measure and monitor the holistic service experience of business schools is important.

This study therefore develops and validates the extended SERVQUAL instrument for measuring business schools' service quality in an emerging economy. Hypotheses concerning students' assessment of the service quality during and at the post purchase stage (after graduation) are tested.

Students' requirements may not carry equal weights in determining the quality of the services received (Zeithaml et al., 2006) during the service encounters at school and beyond. Student perceptions of and the relative weights they attach to various aspects (dimensions) of the service quality in business schools in Tanzania are established and compared during two periods of time, pre and post-graduation.

Findings are discussed and recommendations to managers of business schools are made for future application of the instrument.

\section{Literature review}

Customers or individuals view an object, event or service rendered as acceptable or unacceptable according to their cognitive evaluations of experiences against their own expectations. Extant confirmation/disconfirmation theories support this view. Expectation-Disconfirmation Theory, among disconfirmation theories, holds that satisfaction is jointly determined by pre-experience expectations and postexperience confirmation/ disconfirmation of expectations. Disconfirmation is the degree to which performance exceeds, equals, or falls short of an individual's expectations, resulting in positive, zero, and negative disconfirmation, respectively (Chao, Wang, Fu \& Yi, 2011). 
Vroom's Valence Instrumentality Expectancy Theory (Van Eerde \& Thierry, 1996), is based on three variables: Valence, Instrumentality and Expectancy. Valence refers to the affective orientation/value towards an outcome - the emotional orientations, which people hold with respect to the outcome (rewards). Positive valence is preferred to negative valence i.e. the person must prefer attaining the outcome rather than not. Instrumentality has an outcome-outcome association (relationship between performance and outcome). Expectancy is an individual's belief about whether a particular goal is attainable (Lawler III \& Suttle, 1973, Van Eerde \& Thierry, 1996).

In the Value Percept Disparity Theory consumer satisfaction/dissatisfaction is considered an emotional response resulting from a cognitive-evaluative process in which the perceptions of (or beliefs about) an object, action, or condition are compared to one's values, needs, wants, or desires. The smaller the disparity between precepts of the object, action, or condition, and consumer's values, the more favourable the evaluation and the greater the positive affect associated with goal attainment, i.e., satisfaction. Conversely, the greater the consumer's value-percept disparity, the less favourable the evaluation, the less positive affect, and the greater the creation of negative affect i.e., dissatisfaction. This theory assumes that: a consumer evaluates one or more aspects of a product or institution or marketplace behaviour; the consumer holds one or more value standard/ norm; and that the consumer makes a thoughtful judgment of the relationship between perceptions and value (s) (Bloemer \& Dekker, 2007).

While confirmation/disconfirmation theories evaluate an outcome i.e. consumer's satisfaction with the product/service, the same disconfirmation theories are used to evaluate consumers'/customers' service quality perceptions of the service delivery process. The constructs, satisfaction and service quality are related but not similar (Parasuraman, Zeithaml \& Berry, 1988). While service quality is an attitude about a product/service, satisfaction is a cognitive evaluation of a product or service in terms of meeting expectations (Lawler III \& Suttle, 1973).

Satisfaction as a process: Satisfaction is a state felt by a person who has experienced service performance in comparison to prior expectations. Satisfaction is a function of relative level of expectations and perceived performance (Hayanash, Abdullah \& Warokka, 2011). In the context of a student, satisfaction is the student's fulfilment response after education services experience.

Customer satisfaction concept centred on process and the definition thereof is adopted in this study. This is because in the service environment, consumption experience consists of collective perceptual, evaluative and psychological processes, which eventually generate consumer satisfaction (Boshoff \& Gray, 2004).

Service quality
Juran (1982) defines quality as "suitable for use", all about fitness (satisfying customer needs), whereas Crosby (1979, 1984) defines quality as "conforming to requirements/specifications" which have been set by the organization as cited in Parasuraman, Zeithaml and Berry (1985: 41) and Palmer (2001: 208), respectively. Quality is "the extent to which a product or service meets and /or exceeds customer expectations" (Sebastianelli \& Tamimi, 2002: 444). Parasuraman et al. (1985: 42) define quality as a comparison of consumer expectations with actual service performance. Further, Garvin (1987: 103) states "quality means pleasing consumers not just protecting them from annoyances".

The above definitions of quality imply that quality can only be defined from the perspective of customers and occurs where an organization supplies goods or services to a specification that satisfies customer needs (Palmer, 2001). The concept of quality control for tangible goods describes quality in terms of conformance to specifications; conformance to requirements; fitness for use; conformance to customer requirements (Ming \& Ing, 2005; Walker \& Johnson, 2006). Manufactured goods have clear specifications for the components of the final product (Harte \& Etchart, 1997).

Quality determination is easy for tangible goods. This is not the case for intangible goods/services. Customers cannot assess the quality of the services they are going to receive beforehand and this raises uncertainties (Gabbott \& Hogg, 1997; Venetis, 1997; Zeithaml et al., 2006). Furthermore, the evaluation of service quality is a process through which a consumer compares his expectations with the service he perceives to have received (Grönroos, 1984). Parasuraman, Zeithaml and Berry (1988) define perceived quality as the degree and direction of discrepancy between the consumer's perception and expectations. On the other hand, Getty and Thomson (1994), as cited in (Palmer, 2001: 210); Gabbott \& Hogg (1997), state that perceived quality may be viewed as a global attitudinal judgment associated with the superiority of the service experience over time.

Addressing education specifically, the Quality Assurance Agency for Higher Education (QAA) for the UK, as cited in Eagle and Brennan (2007: 47), defines education quality as "A way of describing how well the learning opportunities available to students help them to achieve their award. It is making sure that appropriate and effective teaching, support, assessment and learning opportunities are provided for them." In contrast, Cheng and Tam (1997: 23) state: "Education quality is a character of the set of elements in the input, process, and output of the education system that provides services that completely satisfy both internal and external strategic constituencies by meeting their explicit and implicit expectations." The World Declaration on Higher Education (UNESCO, 1998) declared that "quality in higher education is a multi-dimensional concept, which embraces all its functions and activities, teaching and academic programs, research and scholarship, staffing, students, buildings, facilities, equipment, services to community and the academic environment, ... interactive networking." 
Clearly, the aforementioned definitions of the concept of service quality, all focus on fulfilling customer needs and requirements and how well the level delivered by a service provider matches customer expectations. The customer is the judge of the service quality (Cuganesan, Bradley \& Booth, 1997). Given the intangible nature of the services and the fact that quality is an attitude construct, related but not equivalent to satisfaction (Parasuraman et al., 1988), it can be described as the degree and direction of the discrepancy between customer's expectations and perceptions of the service (Bigné, Martínez \& Miquel, 1997; Ham, 2003; Zeithaml et al., 2006).

Service performance is evaluated after the service is experienced. If the customers' expectations are high compared to the perceived service quality received, this results in dissatisfaction. Conversely, if customers' expectations are below the perceived service quality received, then the customer is satisfied (O'Neill \& Palmer, 2004; Zeithaml et al., 2006). Indeed, an awareness of the situations both before and after the service encounter facilitates the identification of service quality deficiencies. Recognizing the shortfall in service delivery allows service organizations to make adjustments to meet and maintain the proper standards, which are necessary for acceptable/adequate service delivery (Zeithaml, et al., 2006). Identification of such shortfalls is possible if measurement of service quality is undertaken on an on-going basis.

In a similar vein, Parasuraman et al. (1988) and Zeithaml et al. (2006), find the underlying factors which consumers use to judge quality of services are their perceptions of the technical outcome delivered by the service providers, the quality of physical surroundings, and their interactions with employees. Five aspects of service quality, which have been identified, are: Reliability, Responsiveness, Assurance, Empathy, and Tangibles (Parasuraman et al., 1988). These five dimensions may be adequate for most services. However, SERVQUAL is not a generic measure of service quality for all services sectors (Parasuraman et al., 1991, Shekarchizadeh, Rasli, \& Huam, 2011). According to Lovelock and Wirtz, (2007), credence services - intangible services which cannot be evaluated with confidence immediately after receipt are the exception (e.g. services provided by the legal, financial and teaching professions). The outcome of the service encounter is obtained much later after the service experience.

\section{Process Outcome}

The motivation for pursuing studies in higher educational (training) institutions is the expected quality of knowledge and skills to be received. The knowledge and skills obtained by students is an outcome, which is realized after students have encountered multiple service experiences while in training at institutions. The five service quality dimensions (Parasuraman et al., 1991) in SERVQUAL measures the functional aspects of the institution or the quality of the service process. The quality of the service outcome is measured on the basis of customer satisfaction with the service. Service quality is an antecedent to satisfaction (Zeithaml et al., 2006). Dabholkar \& Overby (2005) indicate that service quality is related to process factors while service outcomes are closely linked with customer satisfaction. Boshoff and Gray (2004) suggest that customer satisfaction is process oriented and particularly so in services. The multiple service encounters, which students experience during the education delivery process can be appraised for overall student satisfaction (versus satisfaction with a specific transaction).

Since customer satisfaction is realized from the service delivery process (Boshoff \& Gray, 2004), items adapted from Holfold and Reinders (2001) while measuring students' perceptions of the quality of pharmaceutical education are used. For this reason, another measure of the education outcome from business schools' service delivery process, knowledge and skills (Process Outcome) has been added to enhance the SERVQUAL instrument. The six dimensions that determine business schools' service quality are therefore:

- Tangibles - Appearance of physical facilities, equipment, personnel and communication materials

- Reliability - Ability to perform the promised service dependably and accurately

- Responsiveness-Willingness to help customers and provide prompt service

- Assurance - Knowledge, courtesy of employees and their ability to convey trust and confidence.

- Empathy - Caring, individualized attention the organization provides to its customers whereas

- Process Outcome measures satisfaction with the knowledge and skills received from higher education service providers.

\section{Theoretical model and hypotheses}

Demographic variables are important factors to marketers as they facilitate deeper understanding of a customer's product/service preferences, attitude formation, buying decision, etc. (Malhotra \& Birks, 2000). For instance, customers from mature and emerging markets may have different perceptions of the service quality dimensions (Malhotra, Ulgado, Agarwal, Shainesh \& Wu, 2005; Zeithaml et al., 2006). It is worth noting that students, like all consumers, have individual differences. Including a demographic variable in the extended SERQUAL instrument is, thus, necessary.

Empirical evidence shows mixed results on demographic effect on service quality evaluations. Snipes, Thomson, and Oswald's (2006) study of gender biases of performance evaluations indicates that male service providers receive higher rating than female service providers. In evaluation of service quality, Hung's (2002) study on the cognitive and affective components of service quality shows that females tend to rate the empathy dimension higher than men. The study on the impact of service contact type and demographic 
characteristics on service quality perceptions by GanesanLim, Russell-Bennett and Dagger (2008) indicates the difference in service quality perceptions according to the level of contact inherent to the service and consumer age. Neither gender nor income poses differences in service quality perceptions (Ganesan-Lim et al., 2008). Urban and Pratt's (2000) study of bank mergers and service quality perceptions in the US found a significant difference in service quality perceptions based on the demographic characteristics of the respondents gender, ethnicity, education, and income. Ilias, Hassan, Rahman and bin Yasoa (2008) examined gender, race/ethnicity and semester of study of graduate school students in two private universities in Malaysia. No significant relationship between gender, race/ethnicity, semester of study and service quality or with satisfaction was indicated. The evidence from these previous studies indicates that demographic variables may influence service quality perceptions. Students' service quality perceptions of business schools in Tanzania may be influenced by demographics (gender, age, employment status, marital status and professional specialization).

Hypothesis 1: There is no demographic difference in assessment of service quality received from business schools in Tanzania between students' groups.

In marketing, time is considered a valuable factor as it influences consumers' behaviour, decision-making, etc. Literature shows the number of studies conducted on service quality perceptions have mostly been of cross-sectional nature. These studies have ignored the effect of time (O’Neill, 2003). Students' service quality perceptions change with time due to improvements, which may have been made in the course of service delivery or due to new enrolment. The fact that service quality evaluation is a global accumulation of experiences, monitoring service quality over time for improvement undertaking is important. Oldfield and Baron (2001) in the course of developing a service quality measuring instrument for higher education in a UK University, found students' service quality evaluation for first year and final year students varied. A study by Holdford and Reinders (2001) on service quality perceptions of students studying pharmacy during four years of service experience indicated instability of students' service quality perceptions. O'Neill and Palmer's (2001) study on students' service quality perceptions using a modified SERVQUAL during an orientation week and six weeks after the orientation, indicates a decline in students' service quality perception with the passage of time. It is therefore hypothesized that:

Hypothesis 2: There is no difference between overall mean gap scored during $T 1$ and $T 2$.

Hypothesis 3: There is no relationship between service quality dimensions and the overall level of service performance during $T 1$ and T2.

The relationship of the five service quality dimensions (the independent variables) with the overall level of service performance (dependent variable), while controlling for individual differences, is shown in Figure 1. Since the overall quality gap is a sum total of dimensions' gap, a positive relationship between service quality dimensions and the Overall level of service performance is hypothesized (H3).

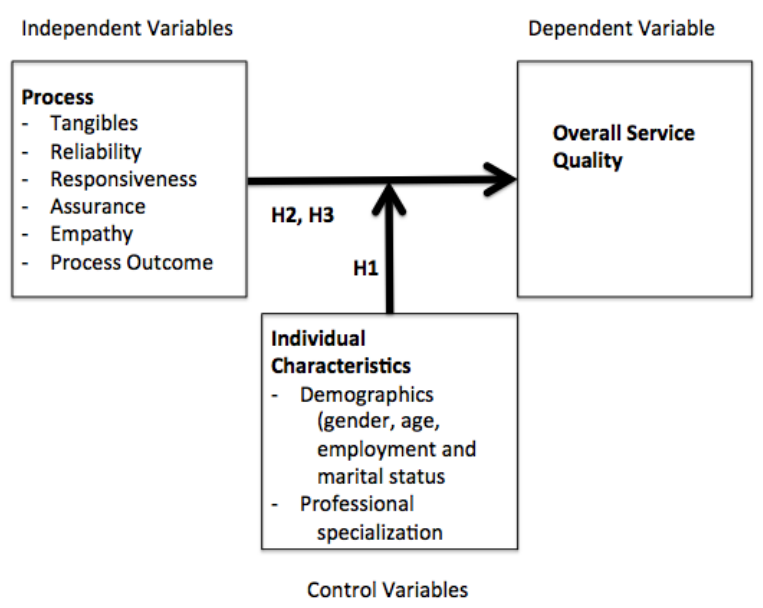

Figure 1: Theoretical model

\section{Methodology}

A longitudinal survey was conducted to test an extended SERVQUAL model in two time periods at two Tanzanian business schools. Students in the final year of study were the units of analysis. The model was used to measure students' (customers') expectations against the school's actual (service) performance (pre and post-graduation) along the Tangible, Reliability, Responsiveness, Assurance and Empathy dimensions and the Process Outcome(s). The first five are general aspects of service quality while the Process Outcome consists of context-specific aspects (Parasuraman et al., 1991). The content of the extended SERVQUAL includes all 22 of the original SERVQUAL items, rephrased to make them suitable for educational institutions, plus six context specific items relating to the students' satisfaction with: the intellectual development/offerings at the institution and the skills and competencies acquired at the institution (Holfold \& Reinders, 2001). The responses to the statements are measured by a Likert type scale (anchored at points 1 to 7 according to the validated instruments). An item asking students to assess the institution's overall performance is also included. Overall performance is measured on a 5-point scale. The content of the added items is given in Table 1. Although student samples are typically not encouraged for use in research (Nel, Heerden, Chan, Ghazisaeli, Halvorson \& Steyn, 2011), students are the target population in this study since they are the consumers of educational services.

\section{Table 1: Process Outcome statements}

\begin{tabular}{ll}
\hline No. & Statement \\
\hline & $\begin{array}{l}\text { Process Outcome } \\
\text { Provision of high quality education } \\
\text { Satisfaction with intellectual development at the }\end{array}$ \\
24 & $\begin{array}{l}\text { institution } \\
25\end{array}$ \\
26 & Satisfaction with the skills acquired at the institution \\
27 & Pride of the accomplishments at the institution \\
28 & Anticipated academic performance \\
\hline
\end{tabular}




\section{Procedure}

The extended SERVQUAL instrument was back-translated by bilingual experts (English-Kiswahili-English) before it was administered. Pre-testing of the instrument was done at a business school in the Netherlands. Students were from emerging economies all over the globe. Students understood all of the items; hence no revision was necessary. Permission from the Commission for Science and Technology and CEOs of business schools in Tanzania was sought before administration of the instrument.

The instrument was administered to students in their final year of study (T1) at two business schools in Tanzania. The same instrument was again administered to the same students (recent graduates) six months after they had graduated (T2). The period of six months after the service encounter conforms to Kirkpatrick and Kirkpatrick's (2006) suggestion of undertaking a behavioural change assessment six months after training is completed. Questionnaires were personally administered to students during their class time after receiving permission from their lecturers during time $\mathrm{T} 1$. During time T2, questionnaires were, again, personally administered to graduates. An incentive of $€ 3$ was offered to encourage a good response rate (Malhotra \& Birks, 2000; Reiche \& Harzing, 2007). A total of 206 recent graduates $(52 \%)$ responded to the second survey. This is an acceptable response rate (Nel et al., 1997; Reiche \& Harzing, 2007; Reimer \& Kuehn, 2005).

\section{Sample characteristics}

The demographic distribution of the student sample is shown in Table 2. The students' modal age group was 25-29 years for both periods of time. There was no significant change in age during the two periods [Paired Sample T-test $(\mathrm{t}(188)=$ $0.663 ; \mathrm{p}=0.508)]$.

During T1 (students in their senior year) and T2 (recent graduates), there were more males than females. The number of employed students increased from $3.6 \%$ in time T1 to 20.9 $\%$ employed graduates in time $\mathrm{T} 2$; however, this was expected since graduates were to be employed after the completion of their studies. The employment rate of graduates after six months may seem low when compared to those in a mature economy. However, this is a normal rate in Tanzania. The relative proportion by professional specialization remained the same in Business Administration, Accountancy and Tax Administration for the two periods of time.

\section{Analysis}

The aggregated gap mean scores $(\Sigma \mathrm{P}-\mathrm{E} / \mathrm{N})$ of responses within each dimension were compared for the two periods of time (T1 \& T2). Internal consistency of the instrument was determined using Cronbach's Alpha. Factor structure and validity of the instrument was examined. Inter-relationships between/within items of the service quality dimensions were determined using Pearson's correlations. A One-way
ANOVA was carried out using the aggregated gap as a dependent variable and participants' perceptions as independent variables to establish and analyse group differences.

\section{Table 2: Sample characteristics}

\begin{tabular}{|c|c|c|c|c|}
\hline \multirow{2}{*}{$\begin{array}{l}\text { Individual } \\
\text { Characteristics }\end{array}$} & \multicolumn{2}{|l|}{ T1 } & \multicolumn{2}{|l|}{$\mathrm{T2}$} \\
\hline & Frequency & $\%$ & Frequency & $\%$ \\
\hline \multicolumn{5}{|l|}{ Age Group } \\
\hline $15-19$ & 1 & 0.27 & & \\
\hline $20-24$ & 66 & 18.13 & 44 & 21.36 \\
\hline $25-29$ & 218 & 59.89 & 126 & 61.17 \\
\hline $30-34$ & 38 & 10.44 & 18 & 8.74 \\
\hline $35-39$ & 5 & 1.37 & 4 & 1.94 \\
\hline $40-44$ & 3 & 0.82 & & \\
\hline Not stated & 33 & 9.07 & 14 & 6.8 \\
\hline Total & 364 & 100 & 206 & 100 \\
\hline \multicolumn{5}{|l|}{ Gender } \\
\hline Male & 223 & 61.3 & 123 & 59.7 \\
\hline Female & 141 & 38.7 & 83 & 40.3 \\
\hline Total & 364 & 100 & 206 & 100 \\
\hline \multicolumn{5}{|l|}{ Marital Status } \\
\hline Married & 26 & 7.1 & 15 & 7.3 \\
\hline Single & 323 & 88.7 & 186 & 90.3 \\
\hline Living together & 12 & 3.3 & 3 & 1.5 \\
\hline Divorced & 1 & 0.3 & 0 & 0 \\
\hline Separated & 1 & 0.3 & 0 & 0 \\
\hline Not stated & 1 & 0.3 & 2 & 1 \\
\hline Total & 364 & 100 & 206 & 100 \\
\hline \multicolumn{5}{|l|}{ Employment Status } \\
\hline Currently Employed & 13 & 3.6 & 43 & 20.9 \\
\hline Not currently employed & 351 & 96.4 & 163 & 79.1 \\
\hline Total & 364 & 100 & 206 & 100 \\
\hline \multicolumn{5}{|l|}{ Professional Specialisation } \\
\hline Business Administration & 64 & 17.6 & 45 & 21.8 \\
\hline Accountancy & 128 & 35.2 & 61 & 29.6 \\
\hline \multicolumn{5}{|l|}{ Procurement and Supply/Logistics } \\
\hline management & 35 & 9.6 & 29 & 14.1 \\
\hline Marketing & 33 & 9.1 & 13 & 6.3 \\
\hline Legal and industrial metrology & 13 & 3.6 & 9 & 4.4 \\
\hline Information Technology & 41 & 11.3 & 23 & 11.2 \\
\hline Tax Administration & 8 & 2.2 & 4 & 1.9 \\
\hline Banking and Finance & 19 & 5.2 & 7 & 3.4 \\
\hline Computer Science & 23 & 6.3 & 15 & 7.3 \\
\hline Total & 364 & 100 & 206 & 100 \\
\hline
\end{tabular}

\section{Findings and discussion}

The aggregated gap mean scores $(\Sigma \mathrm{P}-\mathrm{E} / \mathrm{N})$ and standard deviations for each dimension are presented in Table 3 . The aggregated mean gap scores at time $\mathrm{T} 2$ are lower than those for time $\mathrm{T} 1$ for all dimensions.

The ranking of service dimensions by seniors ( $\mathrm{T} 1$ pre graduation) and recent graduates (T2 post-graduation) are presented in Table 3. The relative importance attached to the dimensions remained the same for $\mathrm{T} 1$ and $\mathrm{T} 2$. However, the magnitude was slightly higher at $\mathrm{T} 2 \mathrm{e.g}$. the degree of importance was 8.4531 (T1) and 8.6808 (T2) with regard to Tangibles. A One-way repeated measure ANOVA indicates a non-significant difference between the aggregated means for the importance of the six dimensions at $\mathrm{T} 1$ and $\mathrm{T} 2$. 
Table 3: Students' aggregated gaps scores and importance attached to service quality dimensions at between time $\mathrm{T} 1$ and time $\mathrm{T} 2$

\begin{tabular}{|c|c|c|c|c|c|c|}
\hline & $\begin{array}{l}\text { Time } \\
\text { T1 }\end{array}$ & $\mathrm{N}=364$ & Rank & $\begin{array}{l}\text { Time } \\
\text { T2 }\end{array}$ & $N=206$ & Rank \\
\hline Dimension & Mean & $\begin{array}{l}\text { Standard } \\
\text { Deviation }\end{array}$ & & Mean & $\begin{array}{l}\text { Standard } \\
\text { Deviation }\end{array}$ & \\
\hline Tangibles & -0.9687 & 1.8397 & 6 & -0.6028 & 1.5377 & 5 \\
\hline Reliability & -1.404 & 2.1694 & 1 & -0.958 & 1.8874 & 1 \\
\hline Responsiveness & -1.3218 & 2.0076 & 3 & -0.8976 & 1.9064 & 2 \\
\hline Assurance & -1.2698 & 1.8191 & 4 & -0.7225 & 1.5244 & 4 \\
\hline Empathy & -1.3465 & 1.9224 & 2 & -0.8754 & 1.6934 & 3 \\
\hline $\begin{array}{l}\text { Process } \\
\text { outcome }\end{array}$ & -0.9876 & 1.5786 & 5 & -0.53 & 1.3284 & 6 \\
\hline Overall gap & -1.198 & 1.5848 & & -0.8564 & 1.4182 & \\
\hline \multicolumn{7}{|c|}{ Degree of Importance attached to Service Quality Dimensions } \\
\hline Dimension & Mean & $\begin{array}{l}\text { Std } \\
\text { Deviation }\end{array}$ & & Mean & $\begin{array}{l}\text { Std } \\
\text { Deviation }\end{array}$ & \\
\hline Tangibles & 8.4531 & 1.935 & 2 & 8.6808 & 1.6867 & 2 \\
\hline Reliability & 8.0482 & 2.5205 & 6 & 8.3189 & 1.9373 & 6 \\
\hline Responsiveness & 8.4291 & 2.1778 & 3 & 8.5767 & 1.8755 & 3 \\
\hline Assurance & 8.4045 & 1.9038 & 4 & 8.522 & 1.788 & 4 \\
\hline Empathy & 8.1411 & 1.9525 & 5 & 8.3294 & 1.8623 & 5 \\
\hline $\begin{array}{l}\text { Process } \\
\text { Outcome }\end{array}$ & 8.9009 & 1.6039 & 1 & 8.9384 & 1.5573 & 1 \\
\hline
\end{tabular}

\section{Validity of the instrument}

The validity of the extended SERVQUAL instrument was tested in the context of an emerging economy, Tanzania, by utilizing it in this longitudinal study.

Reliability: Cronbach's Alpha was computed for the various items for $\mathrm{T} 1$ and $\mathrm{T} 2$ to check the persistence of the internal consistency of this instrument. This ascertains the extent to which items along each dimension shared a common core, given the multidimensionality of the service quality construct (Parasuraman et al., 1988). According to George and Mallery's (2006) interpretation, at T1, the Gaps (P-E) alpha values range from 0.783 to 0.879 . At time T2, the gaps (P-E) alpha values range from 0.741 to 0.883 which are in the range of good to acceptable. The combined reliability for the gaps along all service quality dimensions has been high (0.956 at time T1 and 0.957 at time T2). Though there is no consensus on the proper alpha value (George \& Mallery, 2006), the combined reliability values for the gaps are greater than 0.95 indicating the internal consistency of the instrument. The overall alpha values in this study are better than those reported earlier by Nel, Pitt, and Berthon (1997) using SERVQUAL items only.

\section{Factor structure}

Many previous studies conducted in mature economies have failed to replicate the five factor structure in the original SERVQUAL (Babakus \& Boller, 1992; Boshoff \& Gray, 2004; Carman, 1992; Cronin \& Taylor, 1992; Nel, Pitt \&
Berthon, 1997; O’Neill, 2003; Parasuraman et al., 1991, Pollack, 2009; Shekarchizadeh et al., 2011). In light of this, an exploratory factor analysis was conducted (Principal Component followed by Varimax rotation) for T1 and T2. This was achieved by using a combination of the original SERVQUAL items and the Process Outcome items with the expectation of extracting six factors with respect to Gap scores at two points in time. Factor analysis reveals four components with Eigen values exceeding 1, for both $\mathrm{T} 1$ and $\mathrm{T} 2$ (Table 4). The variance explained was $60.65 \%$ at $\mathrm{T} 1$ and $61.32 \%$ at T2 (Table 4). In all cases the variance explained was higher at time T2. Components with loadings $<0.4$ are ignored as they do not contribute much in the interpretation of the factor structure (Hair, Black, Babin, Anderson \& Tatham, 2006). During time T1, Component 1 is comprised mainly of an amalgamation of items from the Reliability and Responsiveness dimensions; Component 2 is mainly comprised of Empathy items and three items (with relatively lower loading) from the Assurance dimension; Component 3 is made up of the Process Outcome dimension with two items cross loading on Component 2; and Component 4 is comprised of the Tangibles dimension. During time T2, Component 1 is comprised of the Responsiveness, Assurance, and Empathy dimensions; Component 2 consists of Process Outcomes and 1 item from the Empathy dimension with some items cross loading on component 1; Component 3 is comprised of the Reliability items and one item from the Assurance dimension; whereas component 4 is comprised of the Tangibles dimension with one item cross loading on component 3. Although Reliability and Responsiveness came out as one component and Empathy and Assurance as a second component in $\mathrm{T} 1$, in time $\mathrm{T} 2$ the Responsiveness, Assurance, and Empathy dimensions merged into one component (similar to Parasuraman et al., 1991) and Reliability emerged as a more distinctive component. Save for the components' (item) content, the factor structure remained the same for both measurements (pre and postgraduation). The Process Outcome and Tangibles dimensions were found to be consistently distinct. This means students' assessment of the quality of education services delivered by business schools was influenced by the intellectual development of students, the knowledge and skills obtained as well as the status of the facilities/equipment. The management of business schools should therefore ensure the availability and retention of the best faculty. The factor structure for the dimensions measuring functional aspects do not discriminate as well as in some previous studies (Nel, Pitt \& Berthon, 1997, Parasuraman, Zeithaml \& Berry 1991).

\section{Scale validity}

The conceptual and empirical criteria for establishing construct validity include: content/face, convergent, divergent, and criterion validity.

Face validity: The scales involved in this instrument have been adapted from validated instruments; hence the instrument has content validity (Babakus \& Boller, 1991; Carman, 1990; Cronin \& Taylor, 1992: 58). The six items 
constituting the Process Outcome have also been validated (Holdford \& Reinders, 2001).

Table 4: Factor loading matrices for gaps (P-E) time T1 and $\mathrm{T} 2$

\begin{tabular}{|c|c|c|c|c|c|c|c|c|c|}
\hline P-E & & $\mathrm{Tl}$ & & & P-E & & T2 & & \\
\hline & 1 & 2 & 3 & 4 & & 1 & & 3 & 4 \\
\hline Q6 & 0.7585 & & & & Q11 & 0.7307 & & & \\
\hline Q8 & 0.7093 & & & & Q10 & 0.7285 & & & \\
\hline Q12 & 0.6781 & & & & Q12 & 0.7189 & & & \\
\hline Q5 & 0.6655 & & & & Q14 & 0.6243 & & & \\
\hline Q7 & 0.6630 & & & & Q17 & 0.6216 & & & \\
\hline Q11 & 0.6471 & & & & Q20 & 0.6096 & & & \\
\hline Q10 & 0.5934 & & & & Q19 & 0.6011 & & & \\
\hline Q9 & 0.5449 & & & & Q22 & 0.5814 & & & \\
\hline Q13 & 0.4825 & & & & Q16 & 0.5626 & & & \\
\hline Q17 & 0.4598 & & & & Q21 & 0.5588 & 0.4122 & & \\
\hline Q20 & & 0.7574 & & & Q13 & 0.5413 & & & \\
\hline Q18 & & 0.7554 & & & Q28 & & 0.7769 & & \\
\hline Q21 & & 0.6468 & & & Q26 & & 0.7256 & & \\
\hline $\mathrm{Q} 22$ & & 0.6376 & & & Q27 & & 0.7037 & & \\
\hline Q15 & & 0.5679 & & & Q25 & 0.4251 & 0.6500 & & \\
\hline Q16 & 0.4231 & 0.5324 & & & Q24 & 0.4520 & 0.5890 & & \\
\hline Q14 & & 0.4786 & & & Q23 & & 0.5511 & & \\
\hline Q19 & & 0.4409 & & & Q18 & 0.4609 & 0.4615 & & \\
\hline Q25 & & & 0.7818 & & Q8 & & & 0.7517 & \\
\hline Q23 & & & 0.7481 & & Q6 & & & 0.7221 & \\
\hline Q27 & & & 0.7455 & & Q5 & & & 0.7189 & \\
\hline Q26 & & & 0.6784 & & Q9 & & & 0.5872 & \\
\hline Q28 & & 0.4824 & 0.5215 & & Q15 & & & 0.5036 & \\
\hline Q24 & & 0.4247 & 0.5207 & & Q7 & & & 0.4811 & \\
\hline Q1 & & & & 0.7710 & Q3 & & & & 0.7536 \\
\hline $\mathrm{Q} 2$ & & & & 0.7408 & Q2 & & & & 0.7403 \\
\hline Q4 & & & & 0.7192 & Q1 & & & 0.5019 & 0.5919 \\
\hline$Q^{3}$ & & & & 0.5814 & Q4 & & & & 0.4880 \\
\hline KMO & & & 0.9587 & & KMо & & & 0.9435 & \\
\hline BTS & Approx. & Chi square & 5762.464 & & BTS & Approx. & Chi square & 3518.1 & \\
\hline & & & 378 & & & & & 378 & \\
\hline & Sign. & & 0 & & & Sign. & & 0 & \\
\hline & Varianc. & explained & $60.65 \%$ & & & Variance & explained & $61.32 \%$ & \\
\hline
\end{tabular}

Convergent validity: Comparison of the response scores regarding the institutions' level of service (quality) performance with the aggregated mean gaps was made to establish the convergent validity of the instrument for both T1 and T2. During time T1, the comparison of institutions' mean scores on service quality (the independent variable with ratings $1=$ =ery high, 2=High, 3=Medium, 4=Low, and $5=$ Very low) with the aggregated mean gaps (dependent variable) was made, using a One-way ANOVA. Students who positively rated the overall level of service performance also had minimal aggregated gap scores. Similarly, students who scored high with negative aggregated gap scores also rated the level of service performance of the institution low (Parasuraman et al., 1988). The overall mean gap ranged from -0.5883 to -2.50141 . There was a statistically significant difference (at $\mathrm{p}=0.05$ ) between the groups' ratings of service performance. The correspondence between overall mean gap and the level of institution service performance provide evidence of convergent validity of the instrument.

Post-hoc comparisons using the Tukey HSD test indicated the aggregated mean score for the groups, which rated the level of service performance Very High and, conversely, Low were significantly different (at $\mathrm{p}=0.05$ ). Similar results for Time 2 were obtained. The overall mean gap ranged from -0.1207 to -1.2673 .

Correlation analysis of gaps (P-E) for items along the Process Outcome dimension indicate inter-item correlation values that are greater than 0.30 . The results for all other dimensions are similar. According to Hair et al. (2006, p. 137), inter-item correlations should exceed 0.30 . Thus, the correspondence between the aggregated mean gap score and the level of service performance for both $\mathrm{T} 1 \& \mathrm{~T} 2$ and the statistically significant (medium to large) inter-item correlations indicate convergent validity for the extended SERVQUAL instrument.

Divergent/Discriminant validity: The administered instrument in this study contained an item, which asked respondents if they would recommend the institution to others. This variable is associated with service quality since no one would recommend an institution with undesirable service quality performance to a friend. Students who scored high on this item rated the perceived service quality of their institution high, as indicated by the One-way ANOVA results. Aggregated gap scores ranging from -0.5383 to 2.8894 (dependent variable) and perceptions of respondents, ranging from $1-7$ (absolutely not essential to absolutely essential), (independent variable) with regard to recommending an institution to others, indicate that groups who scored below the median score of 4 on the independent variable also had a large negative gap score. Conversely, groups, which scored above 4 had a small negative gap score $(<-1.71$ an average of -0.5383 to -2.6694$)$. There is a statistically significant difference (at $\mathrm{p}=0.05$ ) between students' perception with regard to the seven-point scale of recommending institutions to others. A group of students who felt it essential to recommend the institution to others (scores 6 to 7) also indicated a mean overall gap with a small negative value. Post-hoc comparisons using the Tukey HSD test indicated that Group 7 (absolutely essential to recommend the institution) was significantly different (at $\mathrm{p}=0.05$ ) from other groups on the mean score of the item. During T2, the overall aggregated mean gap scores range from -0.3851 to -0.2286 . A statistically significant difference (at $\mathrm{p}=0.05$ ) was, again, found between students' perceptions on recommending institutions to others. Post-hoc comparisons using the Tukey HSD test indicated a significant difference (at $\mathrm{p}=0.05$ ) between the mean overall gap score of Group 7 and Group 4. These results are similar to those obtained in $\mathrm{T} 1$, to some extent. Gap scores from T1 and T2 indicate a low to medium degree of correlation between dimensions (except the item "The Institution's physical facilities are visually appealing" which indicated medium to high degrees of correlation between dimension items. Low to medium correlation among factors- a pair wise correlation of 0.21 to 0.35 between factors, caused by an overlap among dimensions (responsiveness, assurance, and empathy), has been reported (Parasuraman et al., 1988; 1991).

On the other hand, comparisons of the variance extracted estimates for each factor with the squared inter-construct correlations associated with each factor was made. Component 1 (Variance extracted $=0.566$ ), Component 2 (Variance extracted $=0.606$ ), Component 3 (Variance extracted $=0.6257$ ), and Component 4 (Variance extracted $=0.608$ ) indicate weak discriminant validity.

Criterion validity: Multiple regression analysis coefficients of the dimensions are indicative of the relative importance/ weight of each dimension's contribution to the level of service quality (dependent variable) (Parasuraman et al., 
$1988 ; 1991)$. The four factors extracted from factor analysis were used to predict the level of service performance.

During time T1 only the coefficient for Process Outcome is significant (at $\mathrm{p}=0.05$ ) whereas in time $\mathrm{T} 2$ none of the coefficients for all four dimensions are significantly different from zero. Thus, the contribution of the Process Outcome explains most of the level of service quality performance at $\mathrm{T} 1$ but not at $\mathrm{T} 2$. The contribution of other dimensions is not statistically significant for $\mathrm{T} 1$ or $\mathrm{T} 2$. The variance explained by the model is $10.46 \%$ during T1 and $2.25 \%$ during T2 (at $\mathrm{p}=0.05$ ) (Table 5). From the regression model, the Process Outcome has the largest coefficient (T1), in absolute terms. This means that the Process Outcome dimension has a greater influence on one's assessment of service quality. Component 1, a combination of Reliability and Responsiveness dimensions, is second in rank. This contradicts Reliability's dimension top rank revealed from the studies of Parasuraman et al. (1988, 1991). However, the findings that the Tangibles were given the lowest ranking are different from Parasuraman et al. $(1988,1991)$ for items in the original SERVQUAL as Component 3 ranks third. Though not statistically significant at time T2, Component 2, Process Outcome, has the second largest coefficient. The variance explained by the four dimensions in this study (T1 \& T2) is on the low side when compared to values reported in previous studies in other private service sectors (range 0.08-0.71) [Parasuraman et al. (1988); Parasuraman et al. (1991)]. This means the data does not fit the model well although R-square of 0.8 has been reported. Specific to education services, Pariseau and McDaniel (1996) found 21.0\% of the variance was explained at private business schools while Nel, Pitt \& Berthon, 1997 report an R-square of 0.5 in a study using MBA students in a South African business school using five dimensions compared to the four in this study (original vs. extended model). In this study the sequence of dimensions, based on the magnitude of their coefficients, differs from that found by Parasuraman et al. using the original SERVQUAL model in 1991, for example. This finding supports the contention that the influence of certain aspects of service quality is not the same across all service types (Pollack, 2009). Moreover, the influence of these dimensions also depends on when the assessment is given in the service delivery process (O'Neill \& Palmer, 2001; O'Neill, 2003). The low predictive ability of the extended SERVQUAL for the public business schools in Tanzania may indicate that the domains of the service quality of private business schools in a mature economy may not be the only determinants of service quality in emerging economies, in general, and in Tanzania, in particular. Extraneous variables, (other than the four extracted components) that determine service quality in public business schools, may exist (Nel et al., 1997). For instance, failure to keep promises (Reliability) or tardiness (Responsiveness) in the execution of duties carried out by institutions' employees is more common in Tanzanian (public) business schools. In this context, students could be accustomed to this and accept this as 'normal'. This attitude could be reflected in their responses in school or at places of work. Mature and emerging economies have different cultural orientations and macro environments (Malhotra et al., 2005, Sheth, 2011). Furthermore, the decision making process of public business schools is not necessarily solely within management's jurisdiction. Socio-political factors can play a big role in Tanzania, as business schools have to abide by the government policies and priorities at any given point in time. Elections may impact on who is assigned to the Ministry of Education and how financial resources are allocated, for example (Ministry of Education and Vocational Training, Higher Learning Institutions' Communication, April 8, 2010). The extended SERVQUAL may therefore not be culturally fitted to predict education services quality in a country like Tanzania.

\section{Hypothesis testing}

Three hypotheses are tested.

Hypothesis 1: There is no demographic difference in assessment of service quality received from business schools in Tanzania between students' groups.

One-way between groups ANOVA showed no significant difference between the aggregated dimension scores for male and female students at $\mathrm{T} 1$ whereas at $\mathrm{T} 2$ there was a significant difference found between male and female graduate scores with regard to Empathy $(\mathrm{F}(1,203)=4.2276$, $\mathrm{p}=0.0411)$. This means the perceptions of male and female students on aspects like "courteousness of institution's employees" toward students differed. There was no significant difference found between students' in terms of age group, marital status or employment status at T1 and T2. However, there was a significant difference (at $\mathrm{p}<0.0005$ ) in aggregated scores for the dimensions - Tangibles; Reliability; Assurance; Empathy; Process Outcome and the Overall aggregated gap $(\mathrm{p}=0.039922)$ according to professional specialization. Post hoc tests indicate a significant mean difference for Tangibles between Business Administration and Banking and Finance; Accountancy and Tax Administration; Procurement and Supply/Logistic Management and Banking and Finance; Marketing and Information Technology and Marketing and Computer Science. Similarly, at time T2 there was a significant mean difference between graduate scores by professional specialization for the dimensions Tangibles, Reliability, Empathy and Overall gap. Post hoc testing indicates a significant difference between the Marketing and Banking and Finance specializations with regard to the aggregated scores within the Tangibles dimension $(p=0.035062)$. This means students' perception on service quality on Tangibles items e.g. "institution has up -to-date equipment" differed between professional specializations.

Hypothesis 2: There is no difference between overall mean gap during $T 1$ and $T 2$.

A One-way repeated measure ANOVA indicates no significant difference in the Overall aggregated mean gap between $\mathrm{T} 1$ and $\mathrm{T} 2$ confirming Hypothesis 2. This means student perceptions of service received from business schools in Tanzania remained the same six months after graduation. These results differ from those reported by O’Neill (2003) 
when students were in the orientation process, which showed instability of the students' perceptions.

Hypothesis 3: There is no relationship between service quality dimensions and the overall level of service performance during $T 1$ and $T 2$.
The standardized coefficients (Beta) (T1) in Table 5 indicate low relationship of quality dimensions with the Overall level of service performance, as they are not significantly different from zero, with an exception of Process outcome, which is significantly different from zero. During time T2 standardized coefficients (Beta) for service dimensions are also statistically insignificant.

Table 5: Multiple regression coefficients times T1 and T2

\begin{tabular}{|c|c|c|c|c|c|c|c|c|}
\hline & $\begin{array}{l}\text { Model } \\
1\end{array}$ & T1 & & $\begin{array}{r}\text { Unstandardized } \\
\text { Coefficients } \\
\text { B }\end{array}$ & Std. Error & $\begin{array}{l}\text { Standardized Coefficients } \\
\text { Beta }\end{array}$ & $\mathrm{t}$ & Sig. \\
\hline & & (Constant) & & 2.6080 & 0.0631 & & 41.3261 & 0.0000 \\
\hline & Comp. 1 & Reliability \& Responsiveness & & -0.0726 & 0.0461 & -0.1418 & -1.5767 & 0.1158 \\
\hline & Comp. 3 & Process outcome & & -0.1257 & 0.0445 & -0.2051 & -2.8264 & 0.0050 \\
\hline & Comp. 4 & Tangibles & & -0.0302 & 0.0338 & -0.0578 & -0.8958 & 0.3710 \\
\hline \multirow[t]{20}{*}{ ANOVA } & R Square & & 0.1046 & & & & & \\
\hline & Adj $\quad R$ & & 0.0941 & & & & & \\
\hline & Error of & & 0.9245 & & & & & \\
\hline & Estimate & & & & & & & \\
\hline & $\mathrm{F}$ & & 9.9333 & & & & & \\
\hline & Df & 4,360 & & & & & & \\
\hline & Sig. & & 0.0000 & & & & & \\
\hline & & $\begin{array}{l}\text { T2 } \\
\text { (Constant) }\end{array}$ & & 3.0230 & 0.0760 & & 39.7880 & 0.0000 \\
\hline & Comp. 1 & Empathy_Assurance_Responsiveness & & -0.0966 & 0.0769 & -0.1702 & -1.2563 & 0.2106 \\
\hline & Comp. 2 & Process outcome & & 0.0790 & 0.0779 & 0.1173 & 1.0144 & 0.3117 \\
\hline & Comp.4 & Tangibles & & -0.0276 & 0.0556 & -0.0465 & -0.4965 & 0.6201 \\
\hline & R Square & & 0.0225 & & & & & \\
\hline & $\operatorname{Adj} \quad R$ & & 0.0013 & & & & & \\
\hline & Square & & 0.0013 & & & & & \\
\hline & Standard & & & & & & & \\
\hline & Error of & & 0.9029 & & & & & \\
\hline & Estimate & & & & & & & \\
\hline & $\mathrm{F}$ & & 1.0628 & & & & & \\
\hline & Df & 4,202 & & & & & & \\
\hline & Sig. & & 0.3763 & & & & & \\
\hline
\end{tabular}

\section{Limitations}

Students from two conveniently located (public) business schools in Tanzania were selected for this research. The administration of the instrument to students the second time was within a six-month period. This period may not be long enough to track students' education services quality assessment after graduation. A Likert scale was used in the SERVQUAL instrument. This method of data collection may have not been culturally suitable for the information sought from students. The results on service quality determinants obtained from this study of Tanzanian public business schools may, therefore, not be conclusive. Rather they open future research avenues in similar settings.

\section{Future research avenues}

The SERVQUAL instrument can be administered to a large number of business schools in a similar setting. This will help confirm/disconfirm the determinants of service quality for public versus private business schools in Tanzania. Given the dynamic nature of student and graduate expectations and perceptions, it would be desirable to extend the scope of this longitudinal study beyond the 6-month period used in this study. More can be learned about how perceptions are affected by the passage of time, which also has implications for managers as marketers. The study can be extended to other emerging markets. Other service sectors' quality performance can also be assessed using a context specific extended SERVQUAL model.

\section{Conclusions}

General outcomes: This study has developed and validated the extended SERVQUAL instrument for measuring business schools' service quality in an emerging economy. The instrument was used in a longitudinal study. Students indicated a Perceptions-Expectations mismatch/discrepancy of the service delivered by business schools as depicted by the negative gap scores. All dimensions received negative gap scores with an overall gap score of -1.1980 (T1) and -0.8564 (T2).

Test of Hypothesis 2 indicates no statistical difference between overall gap scores indicated in time T1 and time T2. This means students expectations of education services delivered by the business schools were not fully met. At time $\mathrm{T} 2$, the negative score is small probably because students had already graduated and the lapse of time may have moderated their perceptions (O’Neill \& Palmer, 2001). On the other hand, this may indicate that the services offered by business schools may be within the tolerance zone- desired versus 
expected (Zeithaml et al., 2006). Clearly, in order to be competitive, business schools need to differentiate themselves (Durvasula, Lysonski \& Madhavi, 2011) by offering the best education services. Although the gap scores are negative, the magnitude is relatively small compared to the extreme score of -6 (1-7). However, areas with higher negative gaps may call for immediate redress from business schools managers.

Test of Hypothesis 1 indicates students' perception varying by professional specialization while differences by other demographic variables (age, gender, employment status, and marital status) are not significantly different. Students specializing in different business areas, e.g. in Marketing, and Banking and Finance were found to perceive the service quality on the dimension Tangibles differently. This means that while students specializing in Marketing may not need up-to-date computers, those specializing in Information Technology may deem it necessary. The instrument can then be used to determine which specific criteria groups of students (segments) use to assess the services quality delivered by business schools. Students indicated different weights attached to the service quality dimensions at two points in time. The relative importance (order of weights) remained relatively the same. Students attach more importance to the Process Outcome, followed by Tangibles in both periods of time.

Test of Hypothesis 3 indicates low relationship between the service quality dimensions and the overall level of service performance. Coefficients are significantly not different from zero. However, the Process Outcome (the added new) dimension carries more weight in the prediction of the level of service quality during the service encounter. Indeed Process Outcome is the most motivating factor for students to purchase education services. It is the knowledge and skills which students seek from business schools.

Validity of the instrument: The longitudinal test of the instrument indicates the internal consistency of the instrument is excellent (Alpha >0.95) (George \& Mallery, 2006). Factor analysis has indicated stability of the 4-factor structure for gaps over time, irrespective of the content. The convergent and divergent validities are good when compared to those reported in a mature economy. Regarding criterion validity, multiple regressions indicate that the overall level of service performance of the business schools can largely be predicted by the Process Outcome dimension. However, the predictive ability of the six dimensions (merged into four) is on the low side.

Clearly, cultural orientations of mature and emerging economies may put emphasis on different dimensions/scales. In addition, the environment of emerging countries (sociopolitical arena and level of economic development) differs from that of mature economies. The minor deviations observed (and statistical non-significance of coefficients) do not negate the usefulness of the extended SERVQUAL instrument to managers in educational institutions. Its practical use in public business schools can be meaningful for monitoring, evaluating, and improving service quality.

\section{Managerial implications and recommendations}

The conceptualization of service quality as the discrepancy between students' expectations and the actual performance of business schools can be useful to managers of educational institutions whether in emerging or mature economies. The extended SERVQUAL model can be used to identify the factors students base their quality assessments on with regard to services received. Obviously, future longitudinal and cross-cultural studies can shed more light on service delivery processes and factors, which influence student (customer) perceptions. One additional dimension of this research is the comparison between perceptions of service quality of public business schools' students in an emerging economy, Tanzania, and the perceptions of business schools students in mature economies (from the extant literature). Knowledge of these contexts and the factors which affect the perceptions of all involved will enable managers to periodically assess, sustain and improve quality throughout the whole service delivery process for students and school employees alike. Student satisfaction with the school and employee satisfaction with their educational employer can be maximized. Adding perceptions as a dimension empowers the respondents, whether students or employees, and affirms the significance of their contributing to the quality control of their institution. Priorities can also be set to allocate resources properly to make effective investment decisions in service quality improvement (Zeithaml et al., 2006). This has marketing implications due to an increased awareness of the importance of education and high academic standards and proper allocation of public money to education in light of increased competition worldwide. Students will increasingly evaluate schools in terms of the quality of the education they will receive before they invest their time, energy and money. Likewise, high academic standards can be marketed by schools to attract the best students. On a micro level the extended SERVQUAL model will enable managers to analyse student, employee and departmental differences to fine-tune adjustments in service delivery to meet or surpass expectations in order to maximize student and employee satisfaction, a positive institutional image and word-of-mouth publicity (Smith, et al., 2007).

Public Policy Implications: Currently, business schools in Tanzania are not ranked. This may make schools lax in their education services delivery. Furthermore, there is a lack of criteria to use for allocating financial resources. Regulatory bodies can make use of the instrument used in this study, focusing on students' experience during and after the service encounter, to compare the performance of all business schools in Tanzania as a supplement to traditional measures. The results would make ranking of schools possible and provide valuable information to policy makers.

Currently, in Tanzania, different schools may fall under the auspices of different ministries making the allocation of public funds even more complex. Allocation of funds for capital development and discretionary monies based on the validated instrument in this study would then be done more objectively. Rankings and established criteria would enable 
relevant Ministries to allocate public funds more appropriately and efficiently, based on actual need and promote improvement in facilities and academics, across the board. Getting valuable and timely feedback from students of business schools may also prevent/diffuse the need for (costly) student strikes, which in the past, have required government intervention to alleviate the situation.

\section{References}

Abdullah, F. 2005. 'HEdPERF versus SERVPERF: The quest for ideal measuring instrument of service quality in higher education sector', Quality Assurance in Education, 13(4): 305-328.

Babakus, E. \& Boller, G.W. 1992. 'An empirical assessment of the SERVQUAL scale', Journal of Business Research, 24: 253-268.

Bennington, L. \& Cummane, J. 1997. 'Customer-driven research: The customer value workshop'. In Kunst, P. \& Lemmink, J. (Eds.). Managing service quality volume III. London: Paul Chapman Publishing Ltd, pp. 89-105.

Bigné, E., Martínez, C. \& Miquel, J. 1997. 'The influence of motivation, experience and satisfaction on the quality of service of travel agencies'. In Kunst, P. \& Lemmink, J. (Eds.). Managing service quality volume III. London: Paul Chapman Publishing Ltd, pp. 53-70.

Bloemer, J. \& Dekker, D. 2007. 'Effects of personal values on customer satisfaction: An empirical test of the value percept disparity model and the value disconfirmation model', International Journal of Bank Marketing, 25(5): 276-291.

Boshoff, C. \& Gray, B. 2004. 'The relationships between service quality, customer satisfaction and buying intentions in the private hospital industry', South African Journal of Business Management, 35(4): 27-37.

Carman, J.M. Spring 1990. 'Consumer perceptions of service quality: An assessment of the SERVQUAL dimensions', Journal of Retailing, 66: 31-44.

Chao-Min Chiu, Eric T.G. Wang, Fu-Jong Shih \& Yi-Wen Fan. 2011. 'Understanding knowledge sharing in virtual communities: An integration of expectancy disconfirmation and justice theories', Online Information Review, 35(1): 134-153.

Cheng, Y. C. \& Tam, W. M. 1997. 'Multi-models of quality in education', Quality Assurance in Education, 5(1): 22-31.

Cronin, J.J. Jr \& Taylor, S.A. July 1992. 'Measuring service quality: A re-examination and extension', Journal of Marketing, 56: 55-68.

Cuganesan, S., Bradley, G. \& Booth, P. 1997, 'Service quality and organizational performance indicators', In Kunst, P. \& Lemmink, J. (Eds.). Managing service quality volume III. London: Paul Chapman Publishing Ltd, pp. 161-181.

Cuthbert, P.F. 1996, 'Managing service quality in HE: Is SERVQUAL the answer?', Managing Service Quality, 6(2): 11-16.

Dabholkarr, P.A. \& Overby, J.W. 2005. 'Linking process and outcome to service quality and customer satisfaction evaluations: An investigation of real estate agent service', International Journal of Service Industry management, 16(1): 10-27.
Durvasula,S., Lysonski, S. \& Madhavi, A.D. 2011, 'Beyond service attributes: Do personal values matter?', Journal of Services Marketing, 25/1: 33-46.

Eagle, L. \& Brennan, R. 2007. 'Are students customers? TQM and marketing perspectives', Quality Assurance Journal, 15(1).

Ford, J.B., Joseph, M., \& Joseph, B. 1999, 'Importanceperformance analysis as a strategic tool for service marketers: The case of service quality perceptions of business students in New Zealand and the USA', Journal of Services Marketing, 13(2): 171186.

Gabbott, M., \& Hogg, G. 1997. 'Service dimensions and service quality: An asymmetric approach', In Kunst, P. \& Lemmink, J. (Eds.). Managing service quality volume III. London: Paul Chapman Publishing Ltd, pp.1-9.

Garvin, D. A. 1987. 'Competing on the eight dimensions of quality', Harvard Business Review, 65: 101-109.

Ganesan-Lim, C., Russell-Bennett, R. \& Dagger, T. 2008. 'The impact of service contact type and demographic characteristics on service quality perceptions', Journal of Services marketing, 22(7): $550-561$.

George, D. \& Mallery, P. 2006. SPSS for Windows step by step: A simple guide and reference. Boston: Pearson Education, Inc.

Getty, J.M. \& Getty, R.L. 2003. 'Lodging quality index (LQI): Assessing customers' perceptions of quality delivery', International Journal of Contemporary Hospitality, 15(2): 94-104.

Gi- Du Kang. 2004. 'Service quality dimensions: An examination of Grönroos' service quality model', Managing Service Quality, 14(4): 266-277.

Grönroos, C. 1984. 'Defining marketing: A market-oriented approach', European Journal of Marketing, 23(1): 52-60.

Ham, C.L. 2003. 'Analysing the value of service quality management: Gaining competitive advantages', International Journal of Value-Based Management, 16(16).

Hayanash, J.R., Abdullah, H.H., \& Warokka, A. 2011. 'Service quality and student's satisfaction at higher learning institutions: The competing dimensions of Malaysian Universities' competitiveness', Journal of Southeast Asian Research 2011, 2011: 1-10.

Hair, J.F. Jr., Black, W.C., Babin, B.J., Anderson, R.E., \& Tatham, R.L. 2006. Multivariate data analysis. 6th ed., New Jersey, Upper Saddle River: Pearson Prentice Hall.

Harte, H., \& Etchart, G. 1997. 'Quality and change in the provision of health care: The relationship between chaos and quality. The case study of a Seattle clinic', In Kunst, P. \& Lemmink, J. (Eds.). Managing service quality volume III. London: Paul Chapman Publishing Ltd, pp.149-160.

Harvey, L. 2001. 'Defining and measuring employability', Quality in Higher Education, 7(2): 97-109.

Holfold, D., \& Reinders, T.P. 2001. 'Development of an instrument to assess students perceptions of the quality of pharmaceutical education', American Journal of Pharmaceutical Education, 65: 125-131. 
Hung-C.C. 2002. 'A study on the cognitive and affective components of service quality', Total Quality Management, 13(2): 265-274.

Ilias, A., Hassan, H.F.A., Rahman, R.A. \& bin Yasoa, M.R. 2008. 'Student satisfaction and service quality: Any differences in demographic factors?', International Business Research, 1(4): 131143.

Jurkowitsch, S., Vignali, C. \& Kaufmann, H-R. 2006. 'A student satisfaction model for Austrian higher education providers considering aspects of marketing communications', Special edition on consumer satisfaction-global perspective, 9-23.

Kaplanis, S.N. (n.d.). 'The introduction of quality indicators in the HEI in Europe', Available [online] http://www.lib.teipat.gr/ JeanMon/Papers/QUALITY.pdf.

Kirkpatrick, D.L. \& Kirkpatrick, J.D. 2006. Evaluating training programs. $3^{\text {rd }}$ Edition, San Francisco: Berrett-Koehler Publishers Inc.

Koslowski III, F.A. 2006. 'Quality and assessment in context: A brief review', Quality Assurance in Education, 14(3): 277-288.

Lawler, E.E. \& Suttle, J.L. 1973. 'Expectancy theory and job behaviour', Organizational Behaviour and Human Performance, 9: 482-503.

Lovelock, C. \& Wirtz, J. 2007. Services marketing, people, technology, strategy. $6^{\text {th }}$ Edition, Upper Saddle River, NJ: Pearson Prentice Hall.

Ling, K.C., Chai, L.T. \& Piew, T.H. 2010. 'The 'inside-out' and 'outside -in' approaches on students' perceived service quality: An empirical evaluation', Management Science and Engineering, 4(2): 01-26.

Malhotra, N.K. \& Birks, D.F. 2000. Marketing research: An applied approach. European Edition. Edinburgh Gate, England: PrenticeHall, Inc.

Malhotra, N.K, Ulgado, F.M., Agarwal, J., Shainesh, G. \& Wu, L. 2005. 'Dimensions of service quality in developed and developing economies: Multi country cross-cultural comparison', International Marketing Review, 22(3): 256-278.

Mels, G., Boshoff, C. \& Nel, D. 1997. 'The dimensions of service quality: The original European perspective revisited', The Service Industries Journal, 17(1): 173-189.

Ming C.L. \& Ing, S.H. 2005. 'Relationship among service quality, customer satisfaction and profitability in the Taiwanese banking industry', International Journal of Management, 22(4): 635-648.

Nel, D., Boshoff C. \& Mels, G. 1997. 'An empirical assessment of the extended service quality model', South African Journal of Business Management, 28(2): 45-52.

Nel, D., Pitt, L.F. \& Berthon, P.R., 1997. 'The SERVQUAL instrument: Reliability and validity in South Africa', South African Journal of Business Management, 28(3): 113-123.

Nel, D., Heerden, G., Chan, A., Ghazisaeli, M., Halvorson, W. \& Steyn, P. 2011. 'Eleven years of scholarly research in the journal of services marketing', Journal of Services Marketing, 25/1: 4-13.
Oldfield, B.M. \& Baron, S. 2000. 'Student perception of service quality', Quality Assurance in Education, 8(2): 85-95.

O'Neill, M. 2003. 'The influence of time on student perceptions of the service quality: The need for longitudinal measures', Journal of Academic Administration, 41(3): 310-324.

O'Neill, M. \& Palmer, A. 2001. 'Survey timing and consumer perceptions of service quality: An overview of empirical evidence', Managing Service Quality, 11(3): 182-190.

O'Neill, M. \& Palmer, A. 2004. 'Cognitive dissonance and the stability of service quality perceptions', Journal of Services Marketing, 18(6): 433-449.

Palmer, A. 2001. Principles of services marketing. 3rd Edition. UK: McGraw-Hill.

Parasuraman, A., Berry, L.L. \& Zeithaml, V.A. 1991. 'Refinement and reassessment of the SERVQUAL scale', Journal of Retailing, 67(4): 420-450.

Parasuraman, A., Zeithaml, V.A. \& Berry, L.L. 1985. 'A conceptual model of service quality and its implication for future research', Journal of Marketing, 49: 41-50.

Parasuraman, A., Zeithaml, V.A. \& Berry, L.L. 1988. 'SERVQUAL: A multiple-item scale for measuring consumer perceptions of service quality', Journal of Retailing, 64(1):12-40.

Pariseau, S.E. \& McDaniel, J.R. 1997. 'Assessing service quality in schools of business', International Journal of Quality \& Reliability Management, 14(3): 204-218.

Pollack, B.L. 2009. 'Linking the hierarchical service quality model to customer satisfaction and loyalty', Journal of Services Marketing, 23/1: 42-50.

Reimer, A. \& Kuehn, R. 2005. 'The impact of service-cape on quality perception', European Journal of Marketing, 39 (7/8): 785808.

Reiche, B.S. \& Harzing, A.W. 2007. Key issues in international survey research. Available [online] http://www.harzing.com/ intresearch_keyissues.htm.

Sebastianelli, R. \& Tamimi, N. 2002. 'How product quality dimensions relate to defining quality', International Journal of Quality \& Reliability management, 19(4): 442-453.

Shekarchizadeh, A., Rasli, A. \& Huam T. 2011. 'SERVQUAL in Malaysian universities: Perspectives of international students', Business Process Management Journal, 17(1): 67-81.

Smith, G., Smith, A. \& Clarke, A. 2007. 'Evaluating service in universities: A service department perspective', Quality Assurance in Education, 15(3): 334-351.

Snipes, R.L., Thomson, N.F. \& Oswald, S.L. 2006. 'Gender bias in customer evaluations of service quality: An empirical investigation', Journal of Services Marketing, 20(4): 274-284.

Sheth, J.N. 2011. 'Impact of emerging markets on marketing: Rethinking existing perspectives and practices', Journal of Marketing, 75:166-182. 
Sweeny, J.C., Soutar, G.N. \& Johnson, L. W. 1996. 'Are satisfaction and dissonance the same construct? A preliminary analysis', Journal of Consumer Satisfaction, Dissatisfaction and Complaining Behaviour, 9:138-143.

Teas, R.K. October 1993. 'Expectations, performance evaluation, and consumers' perceptions of quality', Journal of Marketing, 57:18-34.

Urban, D. \& Pratt, M.D. 2000. 'Perceptions of banking services in the wake of bank mergers: An empirical study', Journal of Services Marketing, 14(14).

UNESCO 1998, October 8. World declaration on higher education for the $21^{\text {st }}$ Century: Vision and action and framework for priority action for change and development in higher education adopted by the World Conference on Higher Education in the Twenty First Century: Vision and Action. Available [online] http://www.unesco.org/education/educprog/wche/declaration_eng. htm.

Venetis, K. 1997. 'Service quality dimensions of professional business services: Structure and dynamics within long term relationships', In Kunst, P. \& Lemmink, J. (Eds.). Managing service quality volume III. London: Paul Chapman Publishing Ltd, pp.89-105.

Van Eerde, W. \& Thierry, H. 1996. 'Vroom's expectancy models and work-related criteria: A meta-analysis', Journal of Applied Psychology, 81(5): 575-586.

Walker, K. \& Johnson, E. 2006. 'Delivering quality accounting services', Management Accounting Quarterly, 7(4).

Wen-H.C. 1998. 'Benchmarking quality goals in service systems', Journal of Services Marketing, 12(29): 113-128.

Zeithaml, V.A., Berry, M.J. \& Gremler, D.D. 2006. Services marketing: Integrating customer focus across the firm. 4th Edition, Singapore: McGraw - Hill. 